This is an author produced version of a paper published in Biosystems Engineering. This paper has been peer-reviewed and is proof-corrected, but does not include the journal pagination.

Citation for the published paper:

Ahlgren, S., Baky, A., Bernesson, S., Nordberg, Å., Norén, O., Hansson, P-A. (2008) Future fuel supply systems for organic production based on FischerTropsch diesel and dimethyl ether from on-farm-grown biomass.

Biosystems Engineering.

Volume: 99 Number: 1, pp 145-155.

http://dx.doi.org/10.1016/j.biosystemseng.2007.09.011

Access to the published version may require journal subscription. Published with permission from Elsevier.

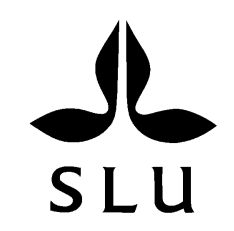

Epsilon Open Archive http://epsilon.slu.se 


\title{
Future fuel supply systems for organic production based on Fischer- Tropsch diesel and dimethyl ether from on-farm-grown biomass
}

\author{
S. Ahlgren ${ }^{1}$; A. Baky ${ }^{2}$; S. Bernesson ${ }^{1}$; Å. Nordberg ${ }^{2}$; O. Norén ${ }^{2}$; P.-A. Hansson ${ }^{1}$ \\ ${ }^{1}$ Swedish University of Agricultural Sciences, Department of Biometry and Engineering, P.O. Box 7032, SE \\ 75007 Uppsala, Sweden; e-mail of corresponding author: serina.ahlgren@bt.slu.se \\ ${ }^{2}$ Swedish Institute of Agricultural and Environmental Engineering (JTI), P.O. Box 7033, SE 75007 Uppsala, \\ Sweden.
}

\begin{abstract}
The effects of making a 1000 ha organic farm self-sufficient in renewable fuel were studied. Biomass grown on-farm can be transported to large fuel production facilities and the fuel transported back to the farm. Two fuels, Fischer-Tropsch diesel (FTD) and dimethyl ether (DME), produced from either straw or short-rotation willow coppice (Salix), were studied. The environmental impact, land use and energy balance were calculated using life-cycle methodology.

It was calculated that the straw-based systems had only $32-39 \%$ of the impact on global warming (kg [CO2-eq]) compared to the Salix-based systems. For acidification and eutrophication, the differences between the systems were less significant. The energy balances were 8.9 and 9.6 for FTD and 10.1 and 10.0 for DME, from straw and Salix, respectively.

To become self-sufficient in FTD, 108 ha has to be set aside for Salix production or 261 ha of straw collected from the existing crop rotation. For DME the corresponding figures are 38 and 70 ha. The many by-products in the FTD scenarios explain the large difference between fuels. Comparing FTD and DME, the differences in environmental impact were small. Considering this, FTD is a more likely alternative since DME requires a pressurised infrastructure system and engine modifications.
\end{abstract}

\section{Introduction}

In recent years organic farming has increasingly become a part of Swedish and European agriculture. In 2003, 16.6\% of Swedish arable land received subsides from the European Union for organic cropping (SJV, 2004). Organic production is defined by a number of principal characteristics drawn up by the International Federation of Organic Agriculture Movements (IFOAM) that are implemented in production standards regulated by control organisations on the national level.

In organic farming, there is an ambition that the production should be based on the use of natural, biological, and renewable resources (IFOAM, 2006). The fossil fuels used today for tractors are limited resources and contributes to global warming (Hansson, 2007). The consumption of diesel oil in organic farming was approximately $50,000 \mathrm{~m}^{3}$ in Sweden during 2003 (calculated from Baky et al., 2002) and this figure should increase as the proportion of organic agriculture increases. Despite this, energy aspects are seldom included in organic farming regulations (Wivstad et al., 2004). 
In recent years, biomass gasification has attracted increasing interest due to the possibility of producing fuels that can be considered as carbon dioxide neutral from a life-cycle perspective. With gasification techniques it is possible to produce, from a wide range of biomass, a number of different fuels such as dimethyl ether (DME), Fischer-Tropsch diesel (FTD), methanol and ethanol. Straw and short-rotation willow coppice (Salix) have previously shown a good energy balance in terms of input versus output from the field (Börjesson, 1994, 1996) and are therefore of great interest if they can be utilised for fuel production.

Several studies and trials on gasification of wood and woody energy crops, mainly for heat and power generation, have been carried out worldwide (Kwant \& Knoef, 2004). A gasification demonstration plant has for example been in operation since 1993 in Värnamo, Sweden. Many different feedstock materials are being tested, including Salix, which was gasified without process problems despite its relatively high levels of alkali (Ståhl et al., 2004).

Most research and development into gasification technology has focused on wood or wood residues. Gasification of straw is regarded as more complicated due to its high content of potassium and chlorine, components that can give rise to deposits and corrosion. Straw also has a high ash content, which can give rise to problems with sintering and deactivation of the catalyst (Skøtt \& Hansen, 2000). However, a number of studies and demonstration projects have confirmed that straw is a promising fuel for gasification. In Denmark, successful tests with straw gasification have been carried out since the 1980s. A small-scale combined heat and power plant based on straw gasification was in operation in Haslev, Denmark, between 1996 and 1999 (Skøtt \& Hansen, 2000). In Copenhagen, the Technical University of Denmark (DTU) has gasified straw in a $50 \mathrm{~kW}$ test facility without the effects of sintering or corrosion occurring. At DTU, a $500 \mathrm{~kW}$ gasification plant has also recently been commissioned. The preliminary test results show that even difficult materials such as manure and straw with an extremely high ash content can be gasified (Nielsen et al., 2005). In Germany, the concept of fast pyrolysis of straw to slurry, which is later gasified in a central plant, is under investigation (Stahl et al., 2005). Within a European Union-funded project, a 3MW straw gasification plant was built and successfully tested during 2000 (STRAWGAS, 2001).It appears that choosing a suitable technique is important for the success of the gasification process. In a study by Asadullah et al. (2004), rice straw with a very high ash content $(22.6 \%)$ was gasified in a dual-bed gasifier with high carbon conversion.

At present, DME is primarily produced from natural gas and is used as a propellant in spray cans. Annual global production is roughly 150,000 metric tonnes, but a new plant is under construction in Iran, which aims to increase world production by over $200 \%$ (Hansen, 2005). Fischer-Tropsch liquids are currently produced on a commercial scale with natural gas and gasified coal as feedstock in plants situated e.g. in Malaysia and South Africa, with a global production of about 8 million metric tonnes per year (Rahmim, 2005). There are no commercial DME or FTD industries currently utilising biomass-based syngas (synthetic natural gas), however, some demonstration projects are in progress and under development; in Freiburg, Germany, Fischer-Tropsch liquids are being produced from biomass in a pilot plant (Rudloff, 2005).

Producing and using a renewable fuel does not necessarily impose a lower environmental burden than fossil alternatives. By observing a system from cradle to grave, differences in environmental burden can be identified. Life cycle assessment (LCA) is a useful tool for analysing a product such as motor fuel during its entire life cycle (Hall \& Scrase, 1998). LCA 
enhances the understanding of how alternative systems compare to each other, but also how different sub-processes in a system affect the overall results (Baumann \& Tillman, 2004).

A common argument against producing renewable fuels for transportation is that biomass can be used more efficiently. According to a study of the UK by Powlson et al. (2005), generating electricity lowers $\mathrm{CO}_{2}$ emissions to a greater extent than producing liquid fuels from the same biomass. Seen in a Swedish context, however, this result cannot be directly translated, as Swedish electricity is mainly generated from hydropower and nuclear power. On a stockless organic farm as in this study, tractor fuel accounts for the largest energy consumption and that is where efforts should be made if organic farming wants to reduce its environmental impact and become independent of fossil resources.

Rape methyl ester (RME), ethanol and biogas have previously been studied from a systems perspective as fuels for self-sustaining organic farms in scenarios that could be implemented using current technology (Fredriksson et al., 2006; Hansson et al., 2007). The results showed that use of biofuels decreased the global warming impact compared to diesel, but that acidification and eutrophication increased. The present study investigated two fuels identified as future solutions, DME and FTD. Fischer-Tropsch diesel is a liquid fuel well-suited for direct use in diesel engines as it has a high cetane number and is sulphur free. Dimethyl ether has very good combustion properties in a diesel engine, but handling and storage are more complicated due to the fact that it is an odourless and colourless gas at ambient conditions, but becomes a thin fluid when slightly pressurised.

In the study by Fredriksson et al. (2006), the raw material and fuel were produced on-farm. In Hansson et al. (2007), the same systems were evaluated for fuel production on an industrial scale. An organic farm can be considered self-sufficient if the biomass is transported to a large-scale fuel production facility and the fuel returned and used on the farm. The technology for gasification, gas cleaning and fuel synthesis is complex and has high investment costs (Tijmensen et al., 2002); therefore these kinds of fuels cannot be produced on-farm, but in large-scale plants.

The objective of this study was to evaluate systems for making organic farms self-sufficient in renewable fuel in a long-term perspective. The energy balance, land use and environmental impact of systems based on FTD and DME from either straw or Salix were investigated using Life Cycle Assessment methodology. The economics and the practical implementation of such systems are also discussed.

\section{Methods}

The environmental performance of the scenarios studied was calculated using the LCA-based methodology described in the ISO 14000 series standards (ISO, 1997, 1998) with some simplifications, namely a limited number of impact categories was studied and only economic allocation was used in the basic scenarios. The energy requirements and emissions contributing to the impact categories studied, from raw material acquisition throughout distribution and processing to end-use, were quantified. The potential environmental load, categorised into different impact categories, was then calculated using equivalency factors. The categories used in this study were land use, energy balance, global warming potential (GWP) for 100 years, acidification potential (AP) and eutrophication potential (AP) using weighting factors from Lindfors et al. (1995) and IPCC (2001). 
The energy balance was calculated by dividing the energy input allocated to the fuel by the energy output in the fuel produced in LHV. The energy input was calculated as primary energy.

The energy input originated from cultivation, collection and transport of raw material and fuel transport. For the fuel production plants, energy used in the process was assumed to be generated internally, for example unreacted syngas was combusted to supply electricity and waste heat was used for drying the incoming biomass.

\subsection{Functional unit}

A common basis of calculation must be defined in order to compare different systems. In this study, the functional unit was the amount of motor fuel needed to cultivate 1000 ha of a given organic crop rotation during one year.

\subsection{Allocation procedures}

Many production systems produce more than one output and therefore the environmental impact of the production system has to be allocated between the main product and the byproducts. For example, cereal growing produces both grain and straw. In this study, it was considered reasonable to divide the energy use and environmental load in relation to the economic value of the main product and the by-products, so called economic allocation (Baumann \& Tillman, 2004).

Difficulties arise when studying cultivation of a single crop because each of the crops in a crop rotation in organic farming systems is affected by the cultivation of other crops. Positive preceding crop effects on nutrient balance, amount of weeds or incidence of diseases may influence the yield of a crop in the rotation. This study used the method for allocation of processes affecting other crops in the rotation developed by van Zeijts et al. (1999). According to this method, the environmental impact of green manure is be allocated to all crops according to their land use in the rotation, because organic matter benefits all crops.

\section{System description}

\subsection{General description and system boundaries}

The time perspective of this study was in a future context. The technology for fuel production from natural gas is currently available on a commercial scale, while the biomass gasification and gas cleaning is still under development. It was estimated that the systems described in this study could be feasible within 10 to 15 years.

The raw material for fuel production was assumed to be cultivated within the 1000 ha of available land and transported to a fuel production plant, and the fuel transported back to the 
farm, where it was utilised. Two fuels and two raw materials were studied, giving a total of four different scenarios (Fig. 1).
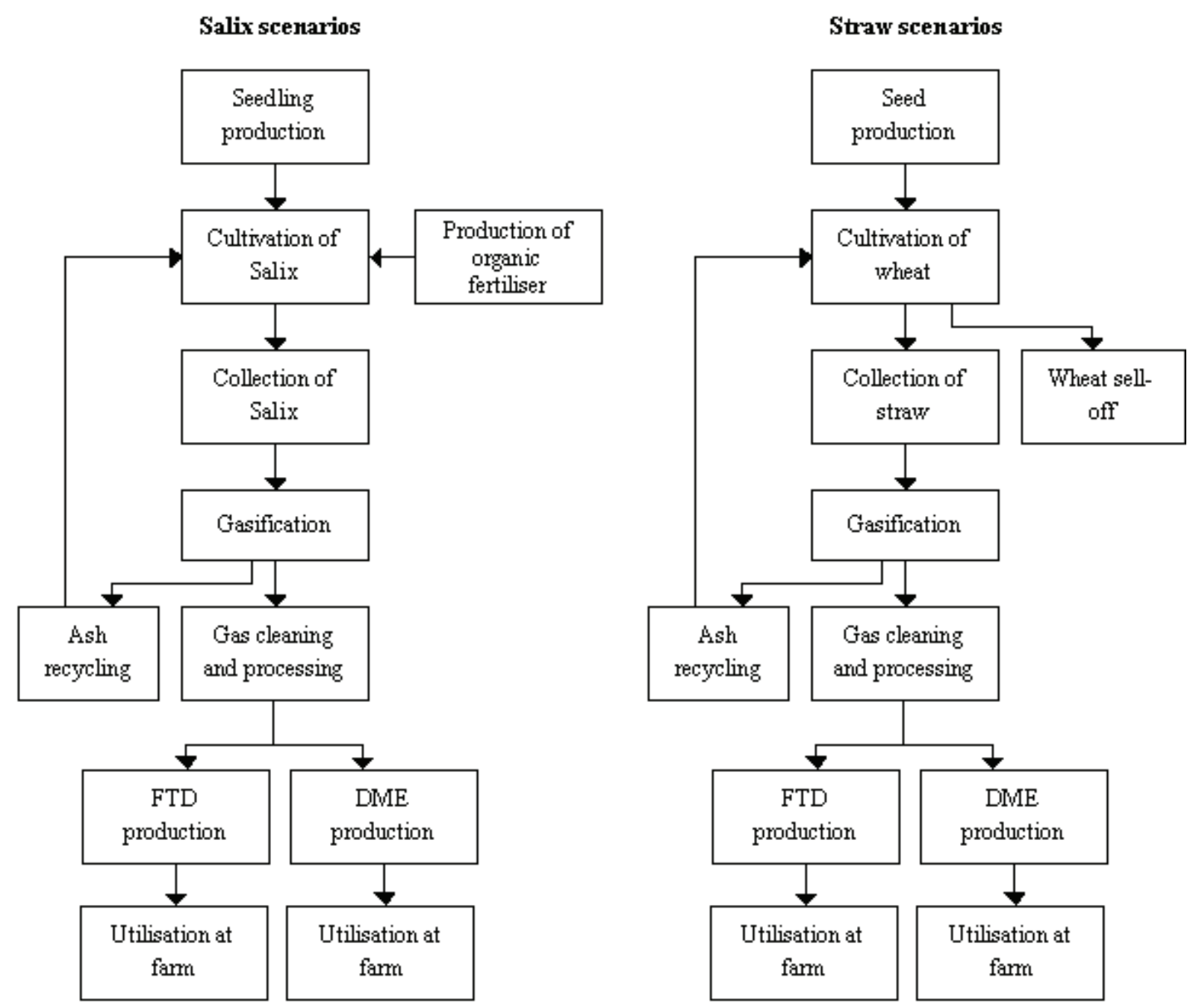

Fig 1. Schematic description of the scenarios Fischer-Tropsch diesel (FTD) and dimethyl ether (DME) from Salix or straw biomass.

Production of capital goods such as machinery and buildings for cultivation and fuel production was not included in the calculations, since Bernesson (2004) showed that production of capital goods in most cases only slightly affects the overall result.

To enable comparisons between the different scenarios, a common crop rotation was defined (Table 1), based on a proven crop rotation from the Logården research farm in south-western Sweden $\left(58^{\circ} 20^{\prime} \mathrm{N}, 12^{\circ} 38^{\prime} \mathrm{E}\right)$ (Helander, 1997). This seven-year crop rotation for stockless organic farming is designed to prevent problems with pests and weeds, to require a minimum of cultivation and to be favourable from an economic perspective. Nitrogen is supplied by nitrogen-fixing crops grown twice in the rotation. The soils are mainly clay loam. The fuel produced was assumed to cover the needs of all operations necessary to cultivate the given crop rotation, including the production of the raw material for the fuel. 


\begin{tabular}{|c|c|c|c|c|c|c|c|c|c|c|c|}
\hline \multirow[b]{2}{*}{ Crop rotation } & \multicolumn{10}{|c|}{ Average annual field operations } & \multirow{2}{*}{ 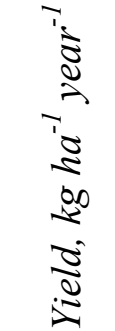 } \\
\hline & 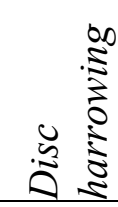 & 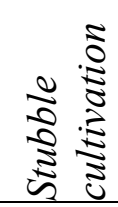 & 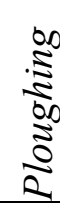 & 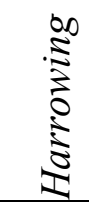 & 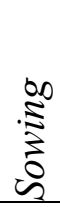 & $\begin{array}{l}\stackrel{0}{\Xi} \\
\stackrel{\Xi}{\Xi} \\
\approx\end{array}$ & 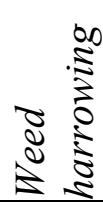 & 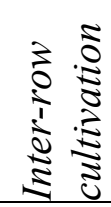 & 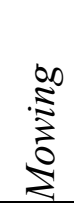 & 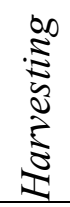 & \\
\hline Field beans & 0.5 & 0.9 & 1 & 3.5 & 1 & 1 & 0.4 & 0.6 & 0 & 1 & 2400 \\
\hline Oats & 0.1 & 0.3 & 1 & 2.5 & 1 & 0.5 & 0.5 & 0.2 & 0 & 1 & 3200 \\
\hline $\begin{array}{l}\text { Green manure } \\
\text { Winter }\end{array}$ & 0 & 0 & 0 & 0 & 1 & 0 & 0 & 0 & 2 & 0 & $6000^{\circ}$ \\
\hline rapeseed & 0.4 & 1.4 & 1 & 3.8 & 1 & 1.8 & 0 & 0 & 0 & 1 & 2000 \\
\hline Winter wheat & 0 & 1 & 1 & 3.6 & 1 & 0.6 & 0.8 & 0.6 & 0 & 1 & 3500 \\
\hline Green manure & 0 & 0 & 0 & 0 & 1 & 0 & 0 & 0 & 2 & 0 & $6000^{2}$ \\
\hline Rye & 0.4 & 0.8 & 1 & 3.6 & 1 & 0.5 & 0 & 0 & 0 & 1 & 3200 \\
\hline
\end{tabular}

\subsection{Production of raw material}

\subsubsection{Scenarios based on Salix}

A share of the 1000 ha of available land was excluded from the crop rotation and used for growing of Salix. The yield of Salix is difficult to estimate as it varies depending on many factors such as choice of variety and location of plantation (Ledin \& Willebrand, 1996). As there were no data available on organically grown Salix, the yield in this study was estimated at $6300 \mathrm{~kg} \mathrm{ha}^{-1} \mathrm{year}^{-1}$, i.e. the same as conventionally grown Salix (Agriwise, 2006). Many plantations in Sweden use mechanical weed control and are fertilised with sludge or other organic fertilisers, much similar to organic production. During the first year of cropping, weed control is required to facilitate seedling development. Once the plants have established however, the need for weed control is reduced (Danfors, 1991).

Because Salix has a lifetime of about 20 years, it needs to be fertilised by means other than nitrogen-fixing crops in the rotation and leaf circulation. In this study, it was assumed that the Salix plantation was fertilised with digestate from a nearby biogas plant operated with ley, using data taken from Fredriksson et al. (2006). Biogas digestate from ley is approved for organic farming. In each cutting cycle (every four years), $150 \mathrm{~kg}[\mathrm{~N}]$ and $17 \mathrm{~kg}[\mathrm{P}]$ were assumed to be applied, which corresponded to $73 \mathrm{t} \mathrm{ha}^{-1}$ of digestate per cutting cycle. Ash from the gasification process, which contains valuable $\mathrm{P}$ and $\mathrm{K}$, was also assumed to be applied to the field. Data for emissions from digestate production were taken from Fredriksson et al. (2006). It was assumed that the digestate was transported $20 \mathrm{~km}$ from the biogas plant to the farm by truck. Salix is harvested and chipped during wintertime when the leaves have fallen; leaves are not desirable in the gasification process and if left on the field the nutrients present can be recycled to the soil. 


\subsubsection{Scenarios based on straw}

Since straw was assumed to be a by-product of on-farm wheat and rye production, it required no land to be set aside. The straw-to-grain ratio by mass was set at 0.85 for wheat and 1.4 for rye (Nilsson, 1999; Lundin, 2001). The straw in this scenario was baled in round large bales before transport to the fuel plant. The allocation of the environmental load between grain and straw was based on the price at the field directly after harvest (Nilsson, 1999), at which the grain had a moisture content of $21 \%$. The straw was left to dry on the field and collected at $15 \%$ moisture content. The allocation factors are presented in Table 2.

Table 2. Economic allocation factors for straw

\begin{tabular}{lccc}
\hline & Yield $^{a}$, ton ha $^{-1}$ & Price $^{b}, \mathrm{Eton}^{-1}$ & Allocation to straw, $\%^{\circ}$ \\
\hline Wheat & 3.77 & 113.1 & \\
Wheat straw & 2.98 & 8.2 & 5.4 \\
Rye & 3.44 & 124.6 & \\
Rye straw & 4.48 & 8.2 & 7.9 \\
\hline
\end{tabular}

${ }^{a}$ Wheat and rye $21 \%$ moisture content, straw at $15 \%$

${ }^{b}$ Price for grain and straw at field after harvest

\subsubsection{Soil emissions}

Data on nitrogen losses to water were taken from Johnsson and Mårtensson (2002) and Dimitriou and Aronsson (2004). Emissions of nitrous oxide and ammonia were calculated using data from Välimaa and Stadig (1998) and Fink et al. (2003). In Salix plantations, fallen leaf litter is not incorporated into the soil and can cause emissions of nitrous oxide. The leaf litter was therefore assumed to give rise to $0.4 \mathrm{~kg} \mathrm{ha}^{-1}$ year $^{-1}$ of nitrous oxide, calculated from Aronsson (2000) and Fink et al. (2003). The losses of phosphorus were assumed to be $0.5 \mathrm{~kg}$ $\mathrm{ha}^{-1}$ year $^{-1}$ for all crops, based on Kyllmar and Johnsson (1996).

\subsection{Fuel production}

\subsubsection{Transport}

The distance between farm and fuel production plant was set to $100 \mathrm{~km}$, and the return of the empty trucks was also included in the calculations. It was assumed that the trucks were run on the same kind of fuel as in the systems studied, i.e. in the FTD scenario the trucks were driven with FTD, although not produced from the farm raw material. The reason for placing the production of transport fuels outside the system boundaries was to enable comparison with previous studies by Hansson et al. (2007). Calculations of fuel consumption for transport of raw material to the fuel plant were based on data from Berggren (1999) and for the distribution of the fuel from NTM (2006).

\subsubsection{Gasification}

Biomass requires a moisture content below 10-15\% when entering the gasification process (McKendry, 2002) and therefore Salix, which is harvested at approximately 50\% moisture content, needs to be dried before the gasification step. Drying is also important to ensure adequate storage of the Salix chips. It was assumed that sufficient low quality waste heat was produced from the fuel production processes to dry the biomass (Tijmensen et al., 2002; Elam, 2002). Straw is usually much dryer at harvest time and in normal weather conditions does not have to be dried before storage. Depending on choice of gasification technique, the 
biomass also has to be reduced in size. The gasification can be carried out with different methods and with different oxidation media, pressures and temperatures (McKendry, 2002). In this study, a oxygen-blown, pressurised gasification unit was assumed to be used. The raw gas from the gasification process needs to be thoroughly cleaned and processed before entering the fuel production step. This includes for example removal of contaminants, reforming, shift conversion and $\mathrm{CO}_{2}$ removal (Tijmensen et al., 2002).

Different fractions of ash are produced during gasification. Fly ash and cyclone ash can contain high amount of metals such as cadmium and can be landfilled or utilised e.g. as fill for road construction. Bottom ash contains valuable phosphorus and potassium, which can be recycled for agricultural use (Pels et al., 2005). In this study, it was assumed that the bottom ash was returned to the field from which the biomass was removed.

\subsubsection{Fischer-Tropsch diesel production}

From synthesis gas, Fischer-Tropsch products can be created over a catalyst in a pressure and temperature controlled reactor. In addition to the diesel fraction, the process also yields a fraction of wax, naphtha, kerosene and flue gas. The wax is cracked to increase the yield of diesel and other liquids, while the flue gas is combusted to provide the process with heat and electricity. Excess electricity can be sold to the national grid, while excess heat can be utilised for drying incoming biomass. Based on Tijmensen et al. (2002), the yield was set to $0.15 \mathrm{MJ}$ diesel lower heat value (LHV), 0.11 MJ [LHV] naphtha and kerosene, and a surplus of $0.22 \mathrm{MJ}$ electricity per MJ [LHV] (30\% moisture content) biomass. Since the differences between using straw and Salix in the process are not fully known, the yield per MJ was assumed to be the same in both cases. The allocation between the co-products was based on economic value relative to the retail price of fossil diesel and electricity on the Swedish market (Nord Pool, 2006; SPI, 2006). Naphtha and kerosene differ slightly in price on the market per energy unit compared to diesel (Asche et al., 2003), but since this difference varies over time, the same price as diesel was assumed. In this way, the FTD carried $31.4 \%$ of the environmental burden. Emissions from the FTD production plant were taken from Marano and Ciferno (2001), PriceWaterhouseCoopers (2003) and Steynberg and Dry (2004).

\subsubsection{Dimethyl ether production}

Dimethyl ether can be produced either by dehydration of methanol or by direct synthesis from synthetic gas (Boding et al., 2003). The direct synthesis process technique is still under development (Semelsberger et al., 2006) and for this study the methanol route was chosen. The yield of DME was set to 0.485 MJ per MJ LHV (50\% moisture content) of biomass, according to the stand-alone scenario in Elam (2002). It was assumed that no useful byproducts were produced in the DME plant. In some studies, excess heat from DME plants is used for district heating. However, the amount of excess heat is uncertain and assumes that there is a requirement in close proximity (Boding et al., 2003). Emissions from the DME plant were taken from Furnander (1996).

\subsection{Fuel storage and distribution}

As FTD has similar properties to diesel, there are no requirements for changes in distribution and handling compared to the current system (Kavalov \& Peteves, 2005). The FTD can be distributed by truck and stored in an ordinary diesel tank at the farm. 
Dimethyl ether is a gas at ambient conditions, but at $20^{\circ} \mathrm{C}$ and pressure over 5 bar becomes liquid. The physical properties of DME are very similar to those of LPG (liquid petroleum gas) for which there already exists a well-developed infrastructure for distribution and storage. In the US, there are farms that utilise LPG for powering tractors. The storage and distribution system of DME can be similar, with minor modifications to pumps, seals and gaskets (Semelsberger et al., 2006). This includes distribution in designated trucks and storage in tanks approved for 16 bar at $20^{\circ} \mathrm{C}$. At the farm, the DME can be stored in aboveground tanks.

\subsection{Fuel utilisation}

Fischer-Tropsch diesel is a fuel well-suited for use in diesel engines. No adjustment of the engine is needed and it has successfully been tested in vehicle fleets. In Sweden, it is today possible to buy FTD produced from fossil sources. The cetane number is high $(>74)$ and it is sulphur free. However, the lubricity is low compared to diesel and some additive may be required. In this study, it was assumed that $200 \mathrm{ppm}$ of fossil-based lubricants were added, as suggested by Norton et al. (1998).

Dimethyl ether is also very well-suited for diesel engines and burns smoothly. Like FTD, it is free from sulphur, nitrogen and metals. Some adjustments have to be made to the tractor engine, e.g. the fuel tank and fuel supply system need to be pressurised. Dimethyl ether has a lower energy content per volume unit and a larger amount of fuel must be supplied to the engine compared to diesel. Further, DME attacks elastomers and thus any plastic and rubber components must be replaced (Semelsberger et al., 2006). Since DME has low lubricity, some additives are needed to prevent problems in the injection system. It was assumed that $1000 \mathrm{ppm}$ of lubricant were added to the DME fuel, as recommended by Hansen and Mikkelsen (2001). Data on emissions from the production of lubricants were taken from Winberg (2002).

Fuel consumption for the tractors used in cultivation were taken from Börjesson (1994), Lindgren et al. (2002) and Elsayed et al. (2003). It was assumed that the fuel consumption of FTD and DME was the same as for diesel on an equal energy basis (Norton et al., 1998; Elam, 2002). As no data were found for emissions from agricultural tractors using the fuels studied, the fuel emissions were set relative to diesel using data from tests in heavy duty trucks (Norton et al., 1998; Gray \& Webster, 2001) (Table 3).

Table 3. Conversion factors for Fischer-Tropsch diesel (FTD) and dimethyl ether (DME) relative to MK1 diesel

\begin{tabular}{llll}
\hline & Diesel & FTD & DME \\
\hline $\mathrm{CO}_{2}$ & 1.00 & 0 & 0.02 \\
NOx, nitrogen oxides & 1.00 & 0.73 & 0.94 \\
\hline
\end{tabular}




\section{Results}

\subsection{Land use}

To become self-sufficient of renewable fuel, biomass was collected within the 1000 ha of available land. In the Salix scenario, the production of FTD required 108 ha and DME 38 ha to be set aside from the crop rotation. The reason for the difference is the large number of byproducts produced in the FTD scenario. In the straw scenario, no land needed to be set aside but 261 ha of wheat and rye straw was collected for FTD and 70 ha for DME.

\subsection{Energy balance and environmental impacts}

The energy balance for FTD from straw and Salix was calculated to be 8.9 and 9.6, respectively, while the energy balance for DME from straw and Salix was calculated to be 10.1 and 10.0.

The potential environmental impacts of the scenarios are presented in Table 4. Soil emissions are presented separately, since they were found to have a large influence on the final results.

Table 4. Potential environmental impact per functional unit (allocated values) for Fischer-Tropsch diesel (FTD) and dimethyl ether (DME) produced from Salix and straw

\begin{tabular}{|c|c|c|c|c|}
\hline & \multicolumn{2}{|c|}{ Salix } & \multicolumn{2}{|c|}{ Straw } \\
\hline & $F T D$ & $D M E$ & $F T D$ & $D M E$ \\
\hline \multicolumn{5}{|c|}{ Global warming potential, $\mathrm{kg}$ [CO $\mathrm{CO}_{2}$-equivalents] } \\
\hline Cultivation/collection of raw material & 1352 & 1574 & 0 & 97 \\
\hline Soil emissions & 18390 & 20804 & 4440 & 4492 \\
\hline Transport of raw material & 1478 & 1216 & 1856 & 1168 \\
\hline Process & 2491 & 199 & 2920 & 210 \\
\hline Transport of fuel & 96 & 112 & 113 & 118 \\
\hline Utilisation of fuel on the farm & 0 & 2047 & 0 & 2128 \\
\hline Total & 23807 & 25952 & 9329 & 8212 \\
\hline \multicolumn{5}{|c|}{ Acidification potential, $\mathrm{kg}$ [SO $\mathrm{SO}_{2}$-equivalents] } \\
\hline Cultivation/collection of raw material & 41 & 48 & 43 & 26 \\
\hline Soil emissions & 142 & 161 & 21 & 21 \\
\hline Transport of raw material & 22 & 13 & 28 & 12 \\
\hline Process & 177 & 21 & 208 & 23 \\
\hline Transport of fuel & 1 & 1 & 2 & 1 \\
\hline Utilisation of fuel on the farm & 226 & 334 & 253 & 327 \\
\hline Total & 610 & 578 & 554 & 409 \\
\hline \multicolumn{5}{|c|}{ Eutrophication potential, $\mathrm{kg}$ [Oㄱ-equivalents] } \\
\hline Cultivation/collection of raw material & 402 & 470 & 365 & 220 \\
\hline Soil emissions & 4773 & 5400 & 4530 & 4472 \\
\hline Transport of raw material & 189 & 108 & 237 & 104 \\
\hline Process & 1523 & 116 & 1785 & 123 \\
\hline Transport of fuel & 12 & 10 & 14 & 10 \\
\hline Utilisation of fuel on the farm & 1934 & 2861 & 2168 & 2799 \\
\hline Total & 8832 & 8965 & 9099 & 7728 \\
\hline
\end{tabular}




\section{Sensitivity and scenario analysis}

Assumptions and choice of data are crucial in LCA-studies and often affect the overall results, which is why a sensitivity analysis is vital. In this study, the distance was set to $100 \mathrm{~km}$ between farm and fuel production. However, since the fuel production facilities were assumed to be large scale, the distance could be longer and the effect of a doubled transport distance was evaluated (Table 5). A $20 \%$ increase in grain yield was also evaluated to accommodate a future increase in the yields of organic cropping. The data on nitrous oxide emissions from soil proved to have a large impact on the results. The soil emissions are difficult to assess as they are dependant on climate, soil type and other local conditions. The effect of a $20 \%$ reduction in nitrous oxide emissions was evaluated in the sensitivity analysis (Table 5).

Of special interest in the FTD scenarios is the allocation between the diesel fraction and the other products. A sensitivity analysis was carried out in which the naphtha brought a $20 \%$ lower price (Table 5). The effect of a change in electricity price was also investigated.

The two straw scenarios showed very good performance in the environmental impact assessment. This was mainly due to the economic allocation between grain and straw and therefore the effect of increased straw prices was studied in the sensitivity analysis (Table 5). An alternative was to allocate the environmental load in relation to the energy content of the products, and thus an analysis was carried out in which all by-products in the systems studied were allocated based on energy content (Table 5).

In the Salix scenarios, it was assumed that the crops were fertilised with sludge from a biogas plant outside the system boundary. However, this burdens the Salix systems with an extra GWP load. A scenario analysis was carried out where the Salix was not fertilised, but the yield lowered by $30 \%$ and the associated soil emissions reduced (Table 5).

The result of the sensitivity and scenario analysis showed that when economic allocation was used, changes in straw price and grain yield did not have a large impact on the GWP results. However, the straw systems were very sensitive to choice of allocation method. This is because in the economic allocation method, the straw takes only a few percent of the environmental impact of the grain, while in the energy content allocation the straw is burdened with almost $50 \%$ of the grain cropping. Since the main purpose of cultivation is to produce grain, physical allocation gives straw an uneven share of the environmental load of cultivation (Bernesson, 2004). Economic allocation was therefore considered to be the best alternative for this study. Furthermore, the Salix scenarios were more sensitive to changes in the nitrous oxide emissions, while the straw scenarios were more sensitive to changes in transport distance. 
Table 5. Changes in global warming potential (GWP, \%) when selected input parameters were changed

\begin{tabular}{lcccccc} 
& \multicolumn{3}{c}{ Change in global warming potential, $\%$} \\
\cline { 2 - 3 } \cline { 5 - 6 } & \multicolumn{2}{c}{ Salix } & & & Straw & \\
\cline { 2 - 3 } \cline { 5 - 6 } & $F T D$ & DME & & FTD & DME \\
\hline Distance farm and fuel production $200 \mathrm{~km}$ & +7 & +5 & & +21 & +16 \\
Wheat and rye yield $+20 \%$ & & & & -8 & -9 \\
Nitrous oxide from soil $-20 \%$ & -15 & -16 & & -10 & -11 \\
Naphtha price $-20 \%$ & +3 & & & +3 & \\
Electricity price $+20 \%$ & -8 & & & -8 & \\
Straw price $+20 \%$ & & & & +9 & +10 \\
Allocation based on energy content & & & & +335 & +411 \\
No sludge, Salix yield -30\% & +21 & +24 & & & & \\
\hline
\end{tabular}

\section{Discussion}

The emissions of nitrous oxide from soil dominated the contribution to global warming potential in all scenarios studied and were closely related to the amount of land used. For the straw scenarios, it was the amount of land allocated to wheat production that determined the size of nitrous oxide emissions. For both DME and FTD, the transport of raw material and fuel to and from the farm was assumed to be carried out with renewable fuels, which explains the quite low impact of transport on global warming. Since the tractors also used renewable fuel, the global warming potential (GWP) of on-farm utilisation of the fuel was not substantial. In the DME scenarios, the additives of fossil origin generated some greenhouse gas emissions. The FTD required only very little additives and the combustion of FTD was considered carbon dioxide neutral. However, in the Salix scenarios the transport and spreading of digestate were included in the cultivation step and gave a contribution to GWP.

The potential acidification was caused by many sources, the largest in all scenarios being utilisation of the fuel. However, both FTD and DME had lower acidification emissions e.g. nitrous oxides (NOx) than diesel (Table 3).

The main share of eutrophication potential was due to soil emissions in the form of nitrogen and phosphorus. In general, a Salix stand has low losses of nutrients to water compared to annual crops. However, since straw was only burdened by a few percent of the wheat cultivations, the soil emissions contributing to eutrophication were lower compared to the Salix scenarios. The FTD process generates reaction water that contains oxygenated compounds, hence the contribution to eutrophication.

Biomass-based FTD and DME are new fuels, and an important issue is their quality compared to existing fuels. In Hansson et al. (2007), the same 1000 ha system as in this study was analysed for use of fossil diesel, RME, ethanol from wheat and biogas from ley. Systems based on straw and Salix as raw material in FTD- and DME-based systems have beneficial properties regarding contribution to global warming, acidification and eutrophication potential compared to the RME, ethanol, biogas and diesel systems studied previously (Table 6). 
In order to assess the sustainability of the new suggested fuels, the costs of production and use compared to existing alternatives are of great significance. The estimated annual cost for a farmer being self sufficient of FTD is $€ 30780$ for straw biomass and $€ 26050$ for Salix (Ahlgren et al., 2007). The corresponding annual costs of DME are $€ 32040$ and $€ 30120$. Dimethyl ether is less expensive to produce, but more expensive to distribute and use. The corresponding costs for RME, ethanol and biogas systems are significantly higher, $€ 94200$, $€ 72950$ and $€ 111$ 240, respectively (Hansson et al., 2007). It is therefore clear that FTD and DME systems have the potential to be competitive in economic terms. The costs include raw material and fuel production, transport of raw material and fuel, farm storage costs and eventual costs for modification of tractors for the new fuels.

When comparing systems, robustness and flexibility are essential factors. Fischer-Tropsch diesel can be handled, stored and used with existing technology and infrastructure for diesel oil and RME. Dimethyl ether, on the other hand, needs a new logistic infrastructure and engine modifications especially adjusted for a single fuel, which is less positive. However, in a specific fleet system as in this study, where the use is for the tractors on the farm only, it can be justified to make such changes if the costs are reasonable. Furthermore, the flexibility in the production of biomass differs between the straw and Salix systems. Salix production has high establishment costs and occupies land for 15-20 years, greatly reducing the flexibility of the system.

Table 6. Environmental impact of systems studied by Hansson et al. (2007) compared to the results of the present study

\begin{tabular}{llccc}
\hline Fuel & $\begin{array}{l}\text { Raw } \\
\text { material }\end{array}$ & $\begin{array}{c}\text { Global warming } \\
\text { potential, } \\
\mathrm{kg}\left[\mathrm{CO}_{2}-\mathrm{eq}\right]\end{array}$ & $\begin{array}{c}\text { Acidification } \\
\text { potential, } \\
\mathrm{kg}\left[\mathrm{SO}_{2}-\mathrm{eq}\right]\end{array}$ & $\begin{array}{c}\text { Eutrophication } \\
\text { potential, } \\
\mathrm{kg}\left[\mathrm{O}_{2}-\mathrm{eq}\right]\end{array}$ \\
\hline Diesel & Rapeseed & 457702 & 1251 & 10542 \\
Rape methyl ester & 43311 & 1639 & 50487 \\
Biogas & Ley & 70095 & 888 & 20495 \\
Ethanol & Wheat & 60234 & 993 & 47214 \\
Fischer-Tropsch diesel & Straw & 9329 & 554 & 9099 \\
Fischer-Tropsch diesel & Salix & 23807 & 610 & 8832 \\
Dimethyl ether & Straw & 8212 & 409 & 7728 \\
Dimethyl ether & Salix & 25952 & 578 & 8965 \\
\hline
\end{tabular}

\section{Conclusions}

One of the aims of organic farming is that the production should be based on renewable resources. However, organic farming uses large amounts of fossil fuel for driving tractors. The objective of this study was to evaluate systems for making an organic farm self-sufficient of renewable fuel. The land use, energy balance and environmental load of systems based on Fischer-Tropsch diesel (FTD) and dimethyl ether (DME) produced from straw and Salix was studied.

The soil emissions of nitrous oxides dominated the potential contribution to global warming in all scenarios. The straw scenarios had only $32-39 \%$ of the global warming impact compared to the Salix systems. However, the results were sensitive to choice of allocation 
method. In the economic allocation method used, the straw only carries $5 \%$ of the soil emission from wheat production. If allocation was based on energy content, the straw would carry $47 \%$. For the acidification and eutrophication impact categories the difference between the systems were less significant but the straw to DME scenario showed the lowest impact. The energy balances were also comparable, 8.9 and 9.6 for FTD from straw and Salix respectively and 10.1 and 10.0 for DME from straw and Salix.

To become self-sufficient of FTD fuel, the farm needs to put aside 108 ha for Salix production, or to collect 261 ha of straw from the existing crop rotation. For DME the corresponding figures are 38 and 70 ha. The large difference between FTD and DME is explained by the many by-products in the FTD scenarios.

The advantages of using straw as raw material is thus the low impact on global warming potential and that it requires no land to be set aside. However, straw is a bulky material and therefore sensitive to transport distance. Furthermore, it can be more complicated to use straw in the gasification process because of its high content of ash, potassium and chlorine, which can cause sintering and corrosion problems.

In the straw scenarios, FTD had only a $12 \%$ higher global warming potential impact than DME. The annual cost for being self sufficient was $€ 30780$ for FTD and $€ 32040$ for DME from straw. Considering the small differences, FTD is a more likely alternative, since DME requires a pressurised infrastructure system and engine modifications.

Compared to using diesel, all the studied scenarios showed better performance in environmental impact. Also compared to biogas, ethanol and RME, the systems were competitive both from an environmental and economical point of view.

\section{References}

Agriwise (2006). Regional profit calculation program for Swedish agriculture. Available from: http://www.agriwise.org. Accessed 2006-05-03

Ahlgren S; Bernesson S; Baky A; Nordberg Å; Norén O; Hansson P A (2007). Self-sufficiency of biofuels - costs for an organic farm in Sweden using FTD or DME. Presented at Bio€ - Success and Visions for Bioenergy. Salzburg, 22-23 March 2007

Aronsson P (2000). Nitrogen retention in vegetation filters of short-rotation willow coppice. Department of Short Rotation Forestry, Swedish University of Agricultural Sciences, Uppsala

Asadullah M; Miyazawa T; Ito S I; Kunimori K; Yamada M; Tomishige K (2004). Gasification of different biomasses in a dual-bed gasifier system combined with novel catalysts with high energy efficiency. Applied Catalysis A-General, 267 (1-2), 95-102

Asche F; Gjolberg O; Volker T (2003). Price relationships in the petroleum market: An analysis of crude oil and refined product prices. Energy Economics, 25 (3), 289-301

Baky A; Hansson P A; Norén O; Nordberg $\AA$ (2002). Grön traktor. Alternativa drivmedel för det ekologiska lantbruket. [Green Tractor. Bio-based Fuels for Use in Organic Farming]. JTI-rapport Lantbruk \& Industri 302, JTI - Swedish Institute of Agricultural Engineering, Uppsala

Baumann H; Tillman A-M (2004). The Hitch Hiker's Guide to LCA. An Orientation In Life Cycle Assessment Methodology And Application. Studentlitteratur, Lund, Sweden

Berggren J (1999). Biobränsletransporter med lastbil och traktor - simulering och analys av bränsleförbrukning och emissioner [Biofuel transport with truck and tractor - simulation and analysis of fuel consumption and emissions]. Report 99:07. Swedish University of Agricultural Sciences, Dep of Agricultural Engineering. Uppsala

Bernesson S (2004). Life cycle assessment of rapeseed oil, rape methyl ester and ethanol as fuels -a comparison between large-and small-scale production. Miljö, teknik och lantbruk, Rapport 2004:01, Department of Biometry and Engineering, Swedish University of Agricultural Sciences, Uppsala

Boding H; Ahlvik P; Brandberg A; Ekbom T (2003). Biomeet II. Stakeholders for biomass based methanol/DME/power/heat energy combine, Trollhättan, Sweden 
Börjesson P (1994). Energianalyser av biobränsleproduktion i svenskt jord- och skogsbruk - idag och kring 2015 [Energy analyses of biomass production in Swedish agriculture and forestry - today and around 2015]. IMES/EESS Report No 17. Institutionen för miljö- och energisystem, Lunds universitet, Lunds tekniska högskola, Lund

Börjesson P (1996). Energy analysis of biomass production and transportation. Biomass \& Bioenergy, 11 (4), 305-318

Danfors B (1991). Mekanisk och kemisk ogräsbekämpning i nyanlagda Salixodlingar [Mechanical and chemical weed control in newly established Salix plantations]. JTI-rapport 129, Swedish Institute of Agricultural Engineering. Uppsala

Dimitriou L; Aronsson P (2004). Nitrogen leaching from short-rotation willow coppice after intensive irrigation with wastewater. Biomass \& Bioenergy, 26 (5), 433-441

Elam N (2002). The bio-DME project. Phase 1. Atrax Energi AB. Report to Swedish National Energy Administration

Elsayed M A; Matthews R; Mortimer N D (2003). Carbon and energy balances for a range of biofuel options. Project Number B/B6/00784/REP, URN 03/836. Resources Research Unit, Sheffield Hallam University, United Kingdom

Fink S; Hammarskjöld G; Pettersson S; Staaf H; Österberg K; Adolfsson R; Ivarsson A K; Lidén M; Kindbom K; Skaårman T; Boström C Å; Peterson H (2003). Sweden's National Inventory Report - submitted under the United Nations convention on climate change. Swedish Environmental Protection Agency, Stockholm

Fredriksson H; Baky A; Bernesson S; Nordberg Å; Norén O; Hansson P A (2006). Use of on-farm produced biofuels on organic farms - Evaluation of energy balances and environmental loads for three possible fuels. Agricultural Systems, 89 (1), 184-203

Furnander $\AA$ (1996). Life cycle assessment of dimethyl ether as a motor fuel. Degree project 96:12, Department of Transportation and Logistics in co-operation with Department of Chemical Environmental Science, Chalmers University of Technology, Gothenburg

Gray C; Webster G (2001). A study of dimethyl ether (DME) as an alternative fuel for diesel engine applications. Prepared for CANMET Energy Technology Centre, Natural Resources Canada and Transportation Development Centre, Transport Canada. Quebec

Hall D O; Scrase J I (1998). Will biomass be the environmentally friendly fuel of the future? Biomass \& Bioenergy, 15 (45), 357-367

Hansen J B (2005). Syngas routes to alternative fuels efficiencies and potential with update on current projects. SYNBIOS conference. 18-20 May 2005, Stockholm, Sweden

Hansen J B; Mikkelsen S-E (2001). DME as a transportation fuel. Prepared for the Danish Road Safety and Transport Agency and the Danish Environmental Protection Agency, Lyngby, Denmark

Hansson P A; Baky A; Ahlgren S; Bernesson S; Nordberg Å; Norén O; Pettersson O (2007). Self-sufficiency of motor fuels on organic farms - Evaluation of systems based on fuels produced in industrial-scale plants. Agricultural Systems in press, doi:10.1016/j.agsy.2007.02.010

Helander C A (1997). The Logården project: development of an ecological and an integrated arable farming system. In: Proceedings of the 4th Congress of the European Society for Agronomy, Veldhoven and Wageningen, The Netherlands, 7-11 July 1996 (van Ittersum, M.K., van de Geijn, S.C. eds), pp. 309-317, Amsterdam and Oxford

IFOAM (2006). The IFOAM norms for organic production and processing. Version 2005. International Federation of Organic Agriculture Movements, Germany.

IPCC (2001). Climate Change 2001: The scientific basis. In: Contribution of working group I to the third assessment report of the Intergovernmental Panel on Climate Change (Houghton J T; Ding Y; Griggs D J; Noguer M; van der Linden P J; Dai X; Maskell K; Johnson C A eds), Cambridge University Press, Cambridge and New York

ISO (1997). Environmental management-life cycle assessment-principles and framework. International Standard ISO 14040 , 1st ed. 1997-06-15, Reference number ISO 14040:1997(E), International Organization for Standardization

ISO (1998). Environmental management - life cycle assessment - goal and scope definition and inventory analysis. EN ISO 14041:1998 E, European Committee for Standardization

Johnsson H; Mårtensson K (2002). Kväveläckage från svensk åkermark - Beräkningar av normalutlakning för 1995 och 1999 [Nitrogen leaching from Swedish farm land - Estimation of normalised leaching 1995 and 1999]. Rapport 5248, Swedish Environmental Protection Agency, Stockholm

Kavalov B; Peteves S D (2005). Status and perspectives of biomass-to-liquid fuels in the European union. European Commission. Directorate General Joint Research Centre. EUR 21745 EN. Petten, The Netherlands

Kwant K W; Knoef H (2004). Status of gasification in countries participating in the IEA and gasnet activity, August 2004. IEA Bioenergy Gasification, EU Gasification Network

Kyllmar K; Johnsson H (1996). Typområden på jordbruksmark (JRK) - Avrinning och växtnäringsförluster för det agrohydrologiska året 1994/95. [Typical areas in agricultural fields - surface run-off and nutrient losses in the year 1994/95]. Ekohydrologi, vol. 40. Division of Water Quality Management, Swedish University of Agricultural Sciences, Uppsala

Ledin S; Willebrand E (1996). Handbook On How To Grow Short Rotation Forests. Department of Short Rotation Forestry. Swedish University of Agricultural Sciences, Uppsala

Lindfors L G; Christiansen K; Hoffman L; Virtanen Y; Juntilla V; Hanssen O J; Rønning A; Ekvall T; Finnveden G (1995). Nordic Guidelines on Life-cycle Assessment, vol. 20, Nordic Council of Ministers, Copenhagen, Denmark.

Lindgren M; Pettersson O; Hansson P A; Norén O (2002). Jordbruks- och anläggningsmaskiners motorbelastning och avgasemissioner - samt metoder att minska bränsleförbrukning och avgasemissioner. [Engine load pattern and engine exhaust gas emissions from off-road vehicles and methods to reduce fuel-consumption and engine exhaust emissions]. JTI-rapport Lantbruk \& Industri 308, JTI - Swedish Institute of Agricultural Engineering, Uppsala

Lundin G (2001). Halmens hackelselängd vid skördetröskning - Tekniska möjligheter och biologiska effekter [Cutting length of straw by combine harvesting - technical possibilities and biological effects]. JTI-rapport, Lantbruk \& industri nr 282. Uppsala 
Marano J J; Ciferno J P (2001). Life-cycle greenhouse-gas emissions inventory for Fischer-Tropsch fuels. Energy and Environmental Solutions, LLC. Prepared for U.S: Department of Energy National Technology Laboratory

McKendry P (2002). Energy production from biomass (part 3): Gasification technologies. Bioresource Technology, 83 (1), 55-63

Nielsen G R; Stoholm P; Nielsen M B; Nørholm N; Antonsen S; Sander B; Krogh J; Henriksen U; Qvale B (2005). The LT-CFB gasifier - first test results from the $500 \mathrm{kw}$ test plant. Presented at the 14th European Biomass Conference \& Exhibition. Paris, France, 17-21 October 2005

Nilsson D (1999). Sham - a simulation model for designing straw fuel delivery systems. Part 1: Model description. Biomass \& Bioenergy, 16 (1), 25-38

Nord Pool (2006). Nordic Power Exchange. Available from: http://www.nordpool.com. Accessed 2006-06-09

Norton P; Vertin K; Bailey B; Clark N N; Lyons D W; Goguen S; Eberhardt J (1998). Emissions from trucks using Fischer-Tropsch diesel fuel. SAE Technical Paper Series, Report No 982526. Warrendale, United States of America

NTM (2006). The Network for Transport and Environment. Available from: http://www.ntm.a.se. Accessed 2006-06-04

Pels J R; Nie D S; Kiel H A J (2005). Utilization of ashes from biomass combustion and gasification. Presented at the 14th European Biomass Conference \& Exhibition. Paris, France, 17-21 October 2005

Powlson D S; Riche A B; Shield I (2005). Biofuels and other approaches for decreasing fossil fuel emissions from agriculture. Annals Of Applied Biology, 146 (2), 193-201

PriceWaterhouseCoopers (2003). Shell middle distillate synthesis (SMDS). Update of a life cycle approach to assess the environmental inputs and outputs, and associated environmental impacts, of production and use of distillates from a complex refinery and smds route. Shell International Gas Limited. Technichal Report v 3.1

Rahmim I I (2005). GTL prospects. Oil and gas journal. International Petroleum News and Technology, Week of Mar. 14

Rudloff M (2005). Operation experiences of Carbo-V process for FTD production. SYNBIOS conference. 18-20 May 2005, Stockholm, Sweden

Semelsberger T A; Borup R L; Greene H L (2006). Dimethyl ether (DME) as an alternative fuel. Journal of Power Sources, 156 (2), 497-511

SJV (2004). Mål för ekologisk produktion 2010. Rapport 2004:19, Swedish Board of Agriculture, Jönköping, Sweden

Skøtt T; Hansen M T (2000). Danish biomass solutions - reliable and efficient. Center for Biomass Technology, The Danish Energy Authority

SPI (2006). The Swedish Petroleum Institute. Available from: http://www.spi.se. Accessed 2006-06-09

Ståhl K; Waldheim L; Morris M; Johansson U; Gårdmark L (2004). Biomass IGCC at Värnamo, Sweden - past and future. GCEP Energy Workshop. Stanford University, CA, USA, April 27, 2004

Stahl R; Henrich E; Kögel A; Raffelt K; Weirich F (2005). The FZK concept of biomass gasification. 1st European Summer School on Renewable Motor Fuels. Birkenfeld, Germany, 29-31 August 2005

Steynberg A P; Dry M E (2004). Fischer-Tropsch Technology. Studies in surface science and catalysis 152. Amsterdam, The Netherlands

STRAWGAS (2001). Straw gasification for co-combustion in large CHP-plants. EU funded project No 1999/C77/15

Tijmensen M; Faaij A; Hamelinck C; van Hardeveld M (2002). Exploration of the possibilities for production of Fischer Tropsch liquids and power via biomass gasification. Biomass \& Bioenergy, 23 (2), 129-152

Välimaa C; Stadig M (1998). Växtnäring i livscykelanalys - mineralgödselanvändning i spannmålsodling. [Nutrients in life cycle assessment]. SIK-report No. 637, The Swedish Institute for Food and Biotechnology, Gothenburg

van Zeijts H; Leneman H; Wegener Sleeswijk A (1999). Fitting fertilisation in LCA: allocation to crops in a cropping plan. Journal of Cleaner Production 7(1), 69-74

Winberg H (2002). LCA for production of re-refined base oil. Industriellt miljöskydd, KTH (Royal Institute of Technology), Stockholm, Sweden

Wivstad M; Milestad R; Lund Y (2004). Regelverk - möjligheter och hinder att uppnå målen för ekologiskt lantbruk [Body of regulation - opportunities and barriers to reach the goals for organic farming]. CUL, Centrum för uthålligt lantbruk, The Centre for Sustainable Agriculture. Uppsala, Sweden 